\title{
Dinamika Sosial Gerakan Guru di Indonesia Pasca Orde Baru
}

\author{
Rakhmat Hidayat \\ email: rakhmat_123@yahoo.com, Universitas Negeri Jakarta
}

\begin{abstract}
Abstrak: Tujuan penulisan artikel ini yaitu: 1) menjelaskan dinamika gerakan guru Indonesia setelah era Orde Baru. Fase ini ditandai dengan bermunculan berbagai organisasi guru di Indonesia dan 2) menjelaskan bagaimana kontribusi gerakan guru Indonesia dalam pentas demokrasi Indonesia. Ada dua kesimpulan penting dalam tulisan ini yaitu: 1) gerakan guru Indonesia yang berkembang setelah era Orde Baru merupakan manifestasi dan artikulasi dari sistem politik yang mendukung munculnya gerakan tersebut; 2) gerakan guru Indonesia menjadi kelompok social penting dalam transisi demokrasi di Indonesia setelah Orde Baru. Metodologi yang digunakan adalah kajian literature dengan mengkaji berbagai referensi terkait gerakan guru di Indonesia. Hal penting yang harus dilakukan oleh gerakan guru di Indonesia adalah melakukan penguatan dan konsolidari jaringan baik jaringan nasional maupun internasional. Dengan cara ini gerakan mereka akan lebih solid, terstruktur dan terlembagakan sebagai actor penting dalam transisi demokrasi di Indonesia.
\end{abstract}

Kata kunci: gerakan, guru, konsolidasi, dan demokrasi

\begin{abstract}
This article aims is to: 1 ) describes the dynamics of movement of teachers in Indonesia after New Order era. This phase is marked by the emerging various teacher organizations in Indonesia and 2) explain how the contribution of Indonesian teachers movement in the stage of democracy in Indonesia. There are two important conclusions in this paper are 1) Indonesian teacher movement that developed after the New Order era is the manifestation and articulation of a political system that supports the emergence of these movements; 2) the movement of Indonesian teachers become an important social group in the transition to democracy in Indonesia after New Order. The methodology used is the study of literature by examining a variety of related references teachers' movement in Indonesia. Movement of teachers in Indonesia have to do the strengthening and consolidation of networks both national and international networks. Their movements will be more solid, structured and institutionalized as an important actor in the transition to democracy in Indonesia.
\end{abstract}

Key words: movement of teacher, consolidation, and democracy

\section{Pendahuluan}

Tanggal 25 November adalah hari istimewa bagi guru Indonesia. Hari itu diperingati sebagai hari Guru Nasional. Momen ini diperingati bertepatan dengan lahirnya Persatuan Guru Republik Indonesia (PGRI). Pada tanggal 25 November 1945, tepat 100 hari setelah proklamasi kemerdekaan. Lahirnya PGRI tak bisa lepas dalam elan vital perjuangan Indonesia saat itu. PGRI memiliki peran penting dalam meletakkan fondasi berhimpunnya guru di Indonesia. Lahirnya PGRI sendiri tidak dalam waktu yang instan. PGRI hadir dari eskalasi perjuangan yang berlangsung sejak zaman kolonial hingga puncaknya Proklamasi kemerdekaan. Sebagai bentuk penghargaan terhadap pengabdian guru, maka diperingati sebagai Hari Guru Nasional pada tanggal tersebut.
Sebagai sebuah wadah menghimpun guru, PGRI mengalami pasang surut dan dinamika tersendiri. Selama Orde Baru, misalnya, ia menjadi aktor tunggal yang sangat akomodatif bagi kekusaan saat itu. Meski demikian, sejarah juga tak dapat menafikan bahwa PGRI masih eksis hingga kini dan peran strategisnya sangat penting dalam perjalanan politik pendidikan di tanah air. Pasca Orde Baru tumbang, PGRI bukan sebagai wadah tunggal berhimpunnya guru-guru di Indonesia. Era reformasi mendorong munculnya berbagai gerakan alternatif selain PGRI. Ketidakpuasan terhadap peran PGRI selama Orde Baru menjadi salah satu alasan. Semangat kebebasan berserikat di kalangan guru menjadi massif di sebagian guru tanah air. Gerakan itu muncul di tingkat nasional maupun lokal. Di level nasional 
sebut saja berdiri Federasi Guru Independen Indonesia (FGII) atau Persaudaraan Guru Sejahtera Indonesia (PGSI). Sementara itu di tingkat lokal bermunculan beberapa wadah seperti Forum Aspirasi Guru Independen (FAGI Bandung) Koalisi Barisan Guru Bersatu (Kobar GB, Nanggroe Aceh Darussalam), Forum Interaksi Guru Banyumas (Figurmas Purwokerto). Tak ketinggalan ormas seperti Nahdlatul Ulama (NU) juga menghimpun guru-gurunya dalam wadah Persatuan Guru Nahdlatul Ulama (Pergunu).

Semangat reformasi memberikan angin segar munculnya berbagai gerakan tersebut. Kesetiaan tunggal yang terjadi di era Orde Baru sebagaimana PGRI menjadi aktor utamanya tidak lagi dominan. PGRI sejatinya menemukan berbagai mitra strategis dalam mengartikulasikan aspirasi dan kepentingan guru. Ruang artikulasi guru tidak lagi mengalami sumbatan sebagaimana terjadi pada rezim Orde Baru. Guru diberikan pilihan untuk bergabung dengan organisasi guru tertentu.

Gerakan guru mempunyai peran yang strategis dalam memperjuangkan kepentingan guru. Sebab apa yang tidak dapat diperjuangkan secara perseorang itu dapat diperjuangkan secara organisasi. Organisasi guru ada untuk memperjuangkan kepentingan guru. Namun gerakan guru belum mampu melakukan pembaharuan terhadap gerakan politik pendidikan kita. Di Inggris, Belanda, dan Swedia misalnya persoalan guru merupakan persoalan harga diri bangsa, bukan persoalan politik semata.

Secara singkat, perumusan masalah tulisan ini adalah: 1) Apa latar belakang berkembangnya gerakan guru di Indonesia setelah era Orde Baru? dan 2) Bagaimana kontribusi gerakan guru Indonesia dalam transisi demokrasi setelah era Orde Baru

Berdasarkan rumusan masalah diatas, tulisan ini disusun untuk menjelaskan: 1) menjelaskan latar belakang berkembangnya gerakan guru di Indonesia setelah era Orde Baru dan 2) menjelaskan kontribusi gerakan guru Indonesia dalam transisi demokrasi setelah era Orde Baru.

\section{Kajian Literatur \\ Definisi tentang Gerakan Sosial}

Gerakan sosial merupakan jawaban spontan maupun terorganisir dari massa rakyat terhadap negara yang mengabaikan hak-hak rakyat, yang ditandai oleh penggunaan cara-cara di luar jalur kelembagaan negara atau bahkan yang bertentangan dengan prosedur hukum dan kelembagaan negara. Gerakan sosial juga bisa dilihat sebagai upaya bersama massa rakyat yang hendak melakukan pembaruan atas situasi dan kondisi sosial politik yang dipandang tidak berubah dari waktu ke waktu atau juga untuk menghentikan kondisi status quo. Menurut Peter Burke, ada dua tipe gerakan sosial. Pertama, gerakan social untuk memulai perubahan. Kedua, gerakan sosial yang dilakukan sebagai reaksi atas perubahan yang terjadi. Bila dikaitkan maknanya dengan gerakan di Indonesia, maka dapat dikategorikan menjadi sebelum dan sesudah 1966. Pada masa sebelum 1966, mobilisasi gerakan sosial mengarah pada pemberian dukungan terhadap legitimasi negara yang baru berdiri. Pasca 1966, gerakan yang terjadi lebih mengarah pada kritik atau reaksi terhadap kebijakan negara, seperti peristiwa Malari, Kedung Ombo, Tanjung Priok, Gerakan Reformasi 1998, dan sebagainya. Gerakan sosial ini jika mengutip Uhlin (1998:16) merupakan manifestasi dari adanya penyebaran ide-ide tentang demokrasi dan demokratisasi yang berlangsung secara massif di seluruh dunia, termasuk Indonesia.

Sebenarnya masih cukup banyak pendapat pakar-pakar ilmu sosial tentang wacana gerakan sosial, yang relevan secara praksis dengan perkembangan gerakan sosial di Indonesia. Gerakan sosial di Indonesia sesungguhnya memiliki akar sejarah yang kuat (Uhlin, 1998:29, Wiratama dalam Hadiz, 2000:xiii). Dimulai sejak perlawanan rakyat Indonesia pada masa kolonialisme Belanda gerakan sosial sebetulnya masih berlanjut sampai sekarang, era Neoliberalisme dengan benderanya Globalisasi. Gerakan petani, buruh, pemuda dan mahasiswa telah menghiasi catatan sejarah gerakan sosial Indonesia. Perlawanan kaum tani sangat militan terhadap kolonialisme Belanda pada 1926 walaupun dapat dipatahkan, kemudian perjuangan bawah tanah para pemuda melawan fasisme Jepang pada masa revolusi kemerdekaan. Hal yang sama juga dilakukan perjuangan kaum buruh menuntut nasionalisasi terhadap perusahaan-perusahaan asing. Masih banyak lagi 
berbagai perlawanan dari masing-masing sektor gerakan sosial Indonesia, termasuk yang dekade 60-an menjadi buah bibir gerakan sosial yakni Gerakan Mahasiswa. Gerakan kaum intelektual ini turut berjasa dalam berbagai aspek, dari proses demokratisasi sampai menghadirkan rezim totaliter. Masih terekam jelas dalam memori rakyat Indonesia saat terjadi mobilisasi gerakan mahasiswa tahun 1966 guna menggulung rezim Orde Lama Soekarno. Kemudian menghadirkan rezim Orde Baru yang lebih otoriter dan militeristik.

Dalam penjelasannya yang lain, Ida (2004) menyebutkan dua paradigma gerakan social yaitu: 1) gerakan sosial lama dan 2) gerakan sosial baru. Gerakan sosial lama lebih karena konflik atau pertentangan yang bersifat material. Penyebab munculnya gerakan sosial ini lebih karena adanya kondisi ketidakadilan dari segi ekonomi yang bersifat struktural. Gerakan yang memperjuangkan peningkatan kesejahteraan buruh dan pengurangan derajat perbedaan atau kesenjangan antarkelompok masyarakat, merupakan bentukbentuk dari gerakan sosial ini. Paradigma kedua menjelaskan gerakan sosial sebagai bagian tidak terpisahkan dari gerakan civil society, menekankan pada bentuk-bentuk partisipasi politik yang tidak konvensional dan tidak melalui lembaga-lembaga formal. Gerakan ini memfokuskan perhatiannya pada isu hak asasi manusia (HAM), kebijakan publik, otonomi, ketergantungan, dan birokratisasi. Sejauh ini studi tentang gerakan guru sebagaimana menjadi payung penelitian ini belum pernah dilakukan, paling tidak berdasarkan penelusuran peneliti di beberapa sumber. Studistudi tentang aktor gerakan sosial berdasarkan penelusuran dokumen banyak dilakukan terkait dengan tema-tema tentang gerakan buruh (Hadiz, 2000:59), gerakan pro demokrasi (Uhlin, 1998), gerakan lingkungan (Dietz, 1998:13).

\section{Sejarah Gerakan Guru di Indonesia}

Pada gerakan guru di Indonesia dapat ditelusuri sejak penjajahan Portugis. Sekolah yang pertama kali didirikan oleh orang-orang Portugis adalah di pulau Ambon pada tahun 1536 (Supriadi, 2003). Pada era penjajahan Portugis ini gerakan guru atau organisasi guru sudah terbentuk, di mana mereka umumnya para pengemban agama Katholik yang ikut serta dalam misi penjajahan
Portugis. Mereka terdiri dari orang-orang Katholik Ordo Jesuit dan Dominikan. Oleh karenanya, organisasi guru ini sering di sebut gerakan guru Ordo Jesuit dan Dominikan. Gerakan guru-guru katholik ini mampu mentransmisikan pendidikan dan ajaran agama katholik diterima penduduk setempat. Gerakan Guru Ordo Jesuit dan Ordo Dominikan. Saat itu kuat dengan pendidikan berbasis agama khatolik.

Pada era penjajahan Inggris, pendidikan dan gerakan guru tidak terorganisir karena pemerintahan Raffles lebih memfokuskan pada usaha pengembangan penelitian tentang Jawa. Gerakan guru era penjajahan Belanda ditandai dengan munculnya Persatuan Guru Hindia Belanda (PGHB) yang kemudian berganti nama menjadi Persatuan Guru Indonesia (PGI). Inilah cikal bakal munculnya organisasi guru yang kita kenal kemudian sebagai PGRI.

Sejarah organisasi guru pada zaman penjajahan Belanda dimulai pada tahun 1894, yaitu dengan dibentuknya organisasi kaum pekerja upahan pertama oleh para guru sekolah dasar dan menengah Belanda (Tedjasukmana, 2008:8). Asosiasi para guru ini dikenal dalam nama Nederlandsch-Indisch Onderwijzers Genootschap (NIOG). Organisasi ini mempertahankan sifat khusus Belandanya, meski demikian organisasi ini seperti dijelaskan Tedjasukmana dalam studinya tentang gerakan buruh di Indonesia tidak pernah memainkan suatu peranan penting dalam gerakan buruh Indonesia. Saat itu, dengan dikeluarkannya para guru Belanda dari sekolah-sekolah publik setelah berdirinya Republik, NIOG menjadi suatu serikat para guru yang kecil di sejumlah sekolah swasta Belanda. Pada tahun 1956, NIOG terdaftar pada Kementrian Perburuhan yang mempunyai enam cabang dengan anggota 320 individu. Tentu saja, dalam konteks gerakan guru Indonesia, kehadiran NIOG menjadi peletak dasar munculnya gerakan guru di tanah air.

Pada tahun 1912 dengan berdirinya Persatuan Guru Hindia Belanda (PGHB) yang diketuai oleh Karto Soebroto. Organisasi ini bersifat unitaristik yang anggotanya terdiri dari para Guru Bantu, Guru Desa, Kepala Sekolah, dan Penilik Sekolah. Dengan latar belakang pendidikan yang berbedabeda mereka umumnya bertugas di Sekolah Desa dan Sekolah Rakyat Angka II yang pelajarannya 
diberikan dalam bahasa daerah ditambah bahasa Melayu. Tidak mudah bagi PGHB memperjuangkan nasib para anggotanya yang memiliki pangkat, status sosial, dan latar belakang pendidikan yang berbeda. Kondisi sosial dan politik waktu itu mempersulit terciptanya kesatuan bahasa dalam perjungan guru; malah sejak perkembangan awal pun sudah tampak adanya gelagat ke arah keretakan perpecahan. Oleh karena itulah, dalam perkembangannya kemudian PGHB merubah nama menjadi Persatuan Guru Indonesia (PGI) tahun 1932. Perubahan ini mengejutkan pemerintah Belanda, karena kata "Indonesia" yang mencerminkan semangat kebangsaan sangat tidak disenangi oleh Belanda. Sebaliknya, kata "Indonesia" ini sangat didambakan oleh guru dan bangsa Indonesia (Yunus dkk, 2003; dalam Supriadi (Ed), 2003)

Pada sisi lain, kejatuhan Orde Baru menjadi sejarah tersendiri dalam peta gerakan guru Indonesia. Hal tersebut menjadi fase berikutnya yang dinamika sosialnya memiliki catatan khusus. Fase ini dapat dikatakan metamorfosa gerakan guru Indonesia dari otoritarianisme ke transisi demokrasi. Sejarah gerakan guru di Indonesia dengan demikian dapat dibagi dalam tiga periode, yaitu periode selama rezim kolonial (mulai dari penjajahan Portugis hingga Jepang). Periode kedua dimulai setelah proklamasi RI pada tanggal 17 Agustus 1945 hingga Orde Baru tumbang. Periode ketiga adalah periode pasca Orde Baru tumbang, persisnya dikenal dengan era reformasi hingga saat ini.

Namun demikian dalam konteks perkembangan kelembagaan formal termasuk di dalamnya keberadaan PGI, pada zaman pendudukan Jepang dilarang dan ditutup. Praktis segala kegiatan pendidikan formal dan plitik membeku. Barulah menjelang Jepang takluk kepada tentara sekutu, sekolah-sekolah mulai dibuka kembali. Akan tetapi pada kenyataannya kebijakan tersebut sarat dengan muatan politis yang membawa misi Nipponisasi dan pemberdayaan bangsa Indonesia untuk perburuhan dan mobilisasi militer (Yunus dkk, 2003; dalam Supriadi (Ed), 2003).

Ada kesadaran dari organisasi-organisasi guru yang kecil untuk berjuang jika dalam faksi-faksi kecil mereka lebih mudah dipatahkan oleh kepentingan kekuasaan. Dengan meleburkan semua perbedaan dan akhirnya menjadi PGRI. Itu terkait dengan situasi sosial-politik zaman penjajahan. PGRI kental sekali dengan kemerdekaan, harus membela perjuangan merah putih. Itu semangat membela tanah air. Itu sebagai ciri khas organisasi perjuangan. Juga sebagai organisasi profesi, dimana organisasi yang mendasarkan pada pengetahuan, keterampilan, pengakuan orang lain. Serta organisasi ketenagakerjaan, tidk bisa dipisahkan untuk meningkatkan kesejahteraan.

PGRI lahir pada 25 November 1945, setelah 100 hari proklamasi kemerdekaan Indonesia. Cikal bakal organisasi PGRI adalah diawali dengan nama Persatuan Guru Hindia Belanda (PGHB) tahun 1912, kemudian berubah nama menjadi Persatuan Guru Indonesia (PGI) tahun 1932. Semangat kebangsaan Indonesia telah lama tumbuh di kalangan guru-guru bangsa Indonesia. Organisasi perjuangan huru-guru pribumi pada zaman Belanda berdiri tahun 1912 dengan nama Persatuan Guru Hindia Belanda (PGHB). Organisasi ini bersifat unitaristik yang anggotanya terdiri dari para Guru Bantu, Guru Desa, Kepala Sekolah, dan Penilik Sekolah. Dengan latar belakang pendidikan yang berbeda-beda mereka umumnya bertugas di Sekolah Desa dan Sekolah Rakyat Angka Dua. Sejalan dengan keadaan itu maka disamping PGHB berkembang pula organisasi guru bercorak keagamaan, kebangsaan, dan yang lainnya.

Selama Orde Baru, guru menjadi komoditas politik dari rezim kekuasaan. Dengan alasan sebagai anggota Korps Pegawai Republik Indonesia (Korpri), guru diminta dan digiring untuk memenangkan Golkar. Guru yang pintar berbicara dan punya kemampuan mempengaruhi massa direkrut jadi juru kampanye (jurkam). Lalu diangkat menjadi anggota DPR atau DPRD. Dalam ketunggalan itulah PGRI mampu "merangkul" seluruh guru di tanah air. Di masa Orde Baru semua organisasi profesi bersandar pada kekuasaan agar eksistensinya diakui, dan mudah bergerak, meskipun secara legitimasi mereka sulit mendapatkannya secara penuh dari anggota. Atau dengan kata lain, banyak organisasi Orde Baru adalah berlegitimasi semu. Legitimasi semu karena dalam satu organisasi kebanyakan pengurus justru bukan berasal dari intern mereka sendiri, misalnya organisasi petani, HKTI, yang 
menjadi pengurusnya bukan penggarap sawah dan ladang, tetapi "petani kota" yang bekas pejabat di instansi pertanian atau insinyur pertanian.

\section{Terbukanya Ruang Politik Pasca Orde Baru}

Pasca reformasi, ruang politik sangat terbuka lebar bagi munculnya berbagai kekuatan alternatif di Indonesia. Monoloyalitas terhadap PGRI tidak lagi terjadi. Meski demikian, PGRI sendiri terus mereposisi dirinya. PGRI tidak lagi menjadi alat kekuasaan, ia perlahan-lahan menjadi kekuatan yang kritis. Meski ia tetap memposisikan dirinya sebagai mitra strategis pemerintah. Pasca reformasi, banyak muncul organisasi guru alternatif di Tanah Air. Menurut Suparman, Ketua Umum Federasi Guru Independen Indonesia (FGII), munculnya gerakan guru alternatif itu berlangsung sejak 1998. Dalam pandangan Muchtar Buchori, munculnya berbagai gerakan alternatif tersebut sebagai bentuk ketidakpuasan terhadap keberadaan PGRI yang terkooptasi oleh politik Orde Baru.

Saat itu mulai ada gerakan kritik dan protes sejumlah guru di beberapa daerah yang menggunakan wadah dan organisasi lain. Pada prosesnya, organisasi lokal tersebut terus melakukan koordinasi dan kontak satu dengan lainnya. Munculnya gerakan guru alternatif ini terjadi secara sporadis, dan tidak terbayang akan menjadi satu kesatuan kemudiannya. Komunikasipun semakin intensif. Puncaknya, pada tanggal 17 Januari 2002 didirikan Federasi Guru Independen Indonesia (FGII) yang menghimpun sebanyak 20 organisasi dan forum guru dari seluruh Indonesia. Ada pula Asosiasi Guru Nanggroe Aceh Darussalam (Asgu-NAD), Koalisi Guru Bersatu (Kobar-GB) Aceh, Ikatan Guru Honorer Indonesia (IGHI) Padang-Sumbar, Forum Martabat Guru Indonesia (FMGI) Lampung, Jakarta Teachers Club (JTC), Forum Aspirasi Guru Independen (FAGI) Kota Bandung, Kabupaten Bandung, Subang, Purwakarta, dan Sumedang. FGII dideklarasikan di halaman Tugu Proklamasi, Jakarta. Saat itu semua organisasi tersebut menyatakan diri untuk bersatu dalam suatu wadah yang disebut Federasi Guru Independen Indonesia. Melalui Kongres I di Bandung pada tanggal 11 - 18 Juli 2002 disepakati bahwa
Federasi tetap mengakui keberadaan masingmasing komponen secara otonom. Pengurus FGII bersifat Presidium, merupakan perwakilan dari berbagai organisasi komponen. Hasil Kongres I FGII menetapkan kepengurusan FGII yang bersifat presidium untuk periode 2002-2005.

Di samping itu juga hadir Forum Interaksi Guru Banyumas (Figurmas) Purwokerto, Lembaga Advokasi Pendidikan (LAP) Jakarta, Forum Komunikasi Guru Tangerang (FKG), Forum GuruGuru Garut (FOGGAR), Forum Guru Tasikmalaya (FGT), Solidaritas Guru Semarang (Sogus), Forum Komunikasi Guru Kota Malang (Fokus Guru), Perhimpunan Guru Tidak Tetap (PGTTI) Kediri, Aliansi Guru Nasional Indonesia (AGNI) Jawa Timur, Perhimpunan Guru Mahardika Indonesia (PGMI) Lombok, dan Forum Guru Honorer Indonesia (FGHI) Jakarta. Begitu banyak dan menjamurnya organisasi guru alternatif yang lahir di era kebebasan berserikat ini. Keberadaan organisasi tersebut mengusung isu hak kesejahteraan yang adil bagi pekerja profesi guru dan terjadinya demokratisasi di dunia pendidikan dengan bergulirnya transparansi dan akuntabilitas dalam setiap kebijakan pendidikan dan keterlibatan guru dalam setiap pengambilan kebijakan pendidikan.

Kini, organisasi guru sebagai organisasi profesi tidak lagi sendirian. Era reformasi telah memungkinkan berdirinya organisasi-organisasi guru selain PGRI. Menurut catatan Kompas (26/ $11)$, sekarang ada lebih dari 20 asosiasi guru, tidak termasuk yang didirikan oleh partai politik. Pada pasal yang sama Butir (h) disebutkan:

Guru berhak memiliki kebebasan untuk berserikat dalam organisasi profesi guru. Pasal ini diperkuat oleh Pasal 41 Ayat 1 yang menyebutkan bahwa: Guru dapat membentuk organisasi profesi yang bersifat independen, juga Pasal 1 Butir (13) yang menyebutkan: Organisasi profesi guru adalah perkumpulan berbadan hukum yang didirikan dan diurus oleh guru untuk mengembangkan profesionalitas guru.

Sejumlah perwakilan guru dari 30 provinsi seIndonesia mendeklarasikan berdirinya Persaudaraan Guru Sejahtera Indonesia (PGSI), pada tanggal 10 September 2006 di Asrama Haji Sukolilo Surabaya. Ide pembentukan PGSI adalah adanya keinginan untuk mengupayakan nasib dan mutu pendidikan di Indonesia, serta peningkatan 
profesionalitas dan kesejahteraan guru. Ide awal teserbut kemudian didukung oleh Undang-undang Nomor 14 Tahun 2005 tentang Guru dan Dosen yang salah satu isinya menyatakan bahwa para guru berhak untuk berserikat. Visi PGSI adalah menjadi pusat pengggerak dan pemberdaya guru. Sedangkan misinya adalah membina dan memelihara integritas, kredibilitas, dan moralitas guru, meningkatkan kompetensi guru, serta memperjaungkan hak-hak dan kesejahteraan guru. Selain itu menjalin kemitraan yang kritis dan konstruktif dengan pemerintah dalam peningkatan mutu pendidikan. Yang bisa masuk sebagai anggota PGSI adalah para guru TK, SD, SMP, SMA, Madrasah, pokoknya guru apa saja yang mempunyai kesamaan perjuangan dan idealismo.

Selain PGSI, sekelompok guru juga menghimpun dirinya dan membentuk organisasi. perjuangan guru yang mampu mengakomodir berbagai perbedaan organisasi-organisasi Guru dalam strategi perjuangan untuk menjadikan guru sebagai profesi yang bermartabat maka beberapa orang komponen Guru yang tergabung dalam Forum Komunikasi Guru Indonesia Sabtu, tanggal 12 Juli 2008 bertempat di Area Lapangan Blok S Kebayoran Baru Jakarta Selatan mendeklarasikan pembentukan Forum Guru Reformasi (FGR) Syarifah Efiana, S.Pd menjadi Ketua Umum FGR untuk selanjutnya memilih personil-personil Pengurus di tingkat Pusat, dan memfasilitasi pembentukan pengurus di tingkat Provinsi dan kabupaten/kota se Indonesia.

\section{Transisi dan Konsolidasi Demokrasi}

Para pendidik kritis seperti Paulo Freire (Freire dalam Darder Antonia, 2003:57), Stanley Aronowitz, Henry A. Giroux (lihat Giroux dalam Darder Antonia, et.all, 2003:51), telah mengungkapkan bahwa guru semestinya dapat menjadi gerakan politik. Namun bukan politik praktis, atau politik kekuasaan, melainkan politik kebudayaan (cultural politic) sebagai upaya masif untuk melakukan perubahan sosial di masyarakat. Gagasan guru sebagai gerakan politik adalah gerakan melawan subkordinasi pembangunan ekonomi dan transaksi politik atas pendidikan. Dengan demikian, guru sebagai gerakan politik harus melawan upaya dari pemerintah atau siapapun yang menjadikan pendidikan sebagai komoditas politik seperti yang terjadi sekarang ini. Pendidikan tidak boleh menjadi batu loncatan karier politik oknum tertentu. Gagasan ini mesti menjadikan guru berani melakukan tekanan politik kepada penguasa untuk menjadikan pendidikan sebagai subjek yang utama dalam pembangunan bangsa, di atas determinan politik dan politik.

Hal ini dilakukan dengan berbagai cara, salah satunya adalah dengan memanfaatkan organisasi-organisasi guru, baik yang formal maupun nonformal. Hal paling substansial dalam jangka panjang guru sebagai gerakan politik kebudayaan ini adalah pendidikan guru. Lembaga Pendidikan Tenaga Kependidikan (LPTK) menjadi institusi pendidikan yang paling bertanggung jawab terhadap kualitas guru yang diluluskannya. Pada fase pendidikan guru inilah, guru mesti disadarkan mengenai relasi kuasa politik dan modal dalam pendidikan, mengenai subordinasi pendidikan oleh ekonomi dan transaksi politik. Kurikulum pendidikan guru mesti memasukkan lebih banyak materi sosiologi pendidikan baru (The New Sociology of Education) yang memaparkan mengenai ideologi pendidikan, politik pendidikan, gerakan politik guru, dan lainnya dengan mengacu pada gagasan-gagasan besar para pendidik kritis seperti Apple dan Giroux.

Penjelasan pemikir-pemikir kritis seperti dijelaskan diatas sejalan dengan penjelasan Budiman (dalam Budiman dan Tornquist, 2000: xxiv) bahwa gerakan guru dapat ditempatkan sebagai salah satu aktor demokrasi. Budiman menjelaskan aktor demokrasi sebagai orang atau sekelompok orang yang melakukan tindakan yang secara langsung maupun tidak langsung membentuk perjuangan untuk menegakkan demokrasi. Munculnya gerakan guru selain PGRI di era reformasi memberikan dampak untuk memperluas ruang demokrasi yang sebelumnya dibatasi. Perjuangan membangun demokrasi yang mana diusung oleh berbagai kekuatan sipil memang bukan perkara mudah, ibarat membalikan telapak tangan. Ruang demokrasi sebenarnya terbuka sebagaimana tidak dialami pada rezim Orde Baru, tetapi gerakan yang massif dari seluruh kekuatan masyarakat sipil termasuk di dalamnya gerakan guru menjadi dasar penting bagaimana gerakkan tersebut mampu mendesak perubahan dan memperkuat demokrasi di 
Indonesia.

\section{Simpulan dan Saran Simpulan}

Berbagai gerakan alternatif pasca Orde Baru sebagaimana dijelaskan diatas sampai sekarang masih terus bekerja untuk memperluas ruang gerak guru untuk mengartikulasikan kepentingannya disamping menjamin hak-hak berorganisasi sebagaimana dijelaskan oleh UU Guru dan Dosen. Gerakan mereka memang masih terkesan reaktif dan sporadis. Gerakan guru era reformasi masih terjebak pada 'urusan perut', belum sampai pada substansi perjuangan mereka, yaitu terlibat dalam politik pendidikan Indonesia. Sebuah perjuangan yang tak mudah tentunya.

Lahirnya gerakan atau organisasi guru alternatif di luar PGRI pada dasarnya positif, namun yang perlu dicermati bahwa lahirnya PGRI pada tahun 1945 sendiri sebenarnya merupakan gabungan dari organisasi-organisasi guru yang ada saat itu. Artinya dalam konteks ini, keberadaan gerakan atau organisasi guru alternatif selagi memberikan kontribusi bagi perjuangan guru, corak boleh berbeda tapi satu tujuan. Memberikan warna dan sebagai sparing parnert/ penyeimbang, bukan pesaing. Sebab jika itu terjadi salah-salah kita seperti sapu yang bercerai berai.

Gerakan-gerakan mereka sejauh ini baru sebatas membentuk sebuah lembaga yang tidak terlalu ketat dan cenderung longgar. Mereka cenderung masih sangat lemah organisasinya dan tidak terkelola dengan baik. Tidak sedikit mereka sangat terkooptasi oleh kekuasaan dan politik. Selain itu mereka juga tidak kuat dana pengelolaan. Lebih dari karena mereka masih terjebak dengan struktur kelembagaan, mereka cenderung tidak memiliki pemikiran-pemikiran (baca:visi strategis) yang memperbarui kondisi saat ini. Belum lagi, meski keberadaan mereka didukung secara legal oleh UU Guru dan Dosen, regulasi yang masih belum memperjelas posisi serikat guru. Selain itu, faktor jaringan juga sangat menentukan. Keberhasilan sebuah gerakan pro demokrasi sangat bergantung kepada kesanggupannya untuk mengaitkan dirinya dengan kelompokkelompok atau organisasi-organisasi besar yang ada di pusat. Sejauh ini gerakan guru di Indonesia dalam kondisi membuka jaringan di masing-masing daerah, meski itu belum maksimal dilakukan. Singkatnya, dua hal menjadi penting. Pertama, masalah kelembagaan merupakan hal penting bagi gerakan guru di Indonesia pasca Soeharto. Seperti mengutip Törnquist, gerakan yang melembagakan perjuangannya secara profesional akan punya nafas yang lebih panjang. Kedua, penguatan jaringan merupakan faktor penting lainnya untuk diperhatikan gerakan guru di Indonesia pasca Orde Baru. Jaringan yang luas bukan saja secara nasional tapi juga secara internasional, akan sangat memperkuat gerakan.

\section{Saran}

Jika merujuk pada studi Hadiz (2000), Uhlin (1998) maupun Budiman dan Tornsquist (2001) tampak kuat bahwa gerakan buruh menjadi aktor yang determinan dalam perubahan sosial di beberapa negara Asia, khususnya Indonesia. Hampir luput dalam studi mereka untuk menempatkan dan dalam konteks yang sangat minim untuk menyinggung gerakan guru. Penjelasannya berbagai studi tersebut dapat diterima karena gerakan guru Indonesia masih seumur jagung, belum tampak memberikan pengaruh dalam kerangka demokrasi Indonesia. Pengalaman Orde Baru memang menunjukkan hal tersebut. Tetapi, pasca Orde Baru, tampaknya kurang lengkap untuk tidak menyinggung dinamika gerakan guru Indonesia dalam studi gerakan sosial maupun demokratisasi. Dua ranah penting kajian yang sejatinya dapat diperdalam berdasarkan studi ini adalah pendekatan demokrasi dan civil society di Indonesia. Studi ini memang sedikit menyinggung bagaimana gerakan guru di Indonesia pasca Orde Baru memiliki saham yang tidak sedikit dalam mentransformasikan demokratisasi di Indonesia. Tetapi itu bukan kajian yang mendalam. Tidak kalah penting dari itu adalah kajian civil society, hal yang sama juga seharusnya menjadi dorongan untuk melakukan studi yang lebih mendalam. Hal penting lainnya adalah gerakan guru Indonesia sebaiknya melakukan penguatan jaringan baik di tingkat nacional maupun internacional. Dengan penguatan ini, gerakan mereka akan lebih solid dalam memperjuangkan hak-hak asasi guru di Indonesia. 


\section{Pustaka Acuan}

Budiman, Arief dan Olle Tornsquist. 2001. Aktor Demokrasi:Catatan tentang Gerakan Perlawanan di Indonesia. Jakarta: ISAI.

Dietz, Ton. 1998. Pengakuan Hak atas Sumber Daya Alam: Kontur Geografi Lingkungan Politik. Yogyakarta: Pustaka Pelajar.

Darder Antonia, 2003. The Critical Pedagogy Reader. New York: Routledge.

Giroux, Henry A. Critical Theory and Educational Practise dalam Darder Antonia, et.all, 2003. The Critical Pedagogy Reader. New York: Routledge.

Hadiz. Vedi R. 2000. Dinamika Kekuasaan: Ekonomi Politik Indonesia Pasca Soeharto. Jakarta: LP3ES

Ida, Laode. 2004. NU Muda: Kaum Progresif dan Sekularisme Baru. Jakarta: Erlangga.

Supriadi, Dedi (Ed.). 2003. Guru di Indonesia: Pendidikan, Pelatihan, dan Perjuangannya sejak Zaman Kolonial hingga Era Reformasi. Jakarta: Depdikbud.

Tedjasukmana, Iskandar. 2008. Watak Politik Gerakan Serikat Buruh Indonesia (terjemahan Oey Hay Djoen). Ithaca: Seri Modern Indonesia Project Southeast Asia Program Department of Far Eastern Studies Cornell University.

Uhlin, Anders. 1998. Oposisi Berserak: Arus Deras Demokratisasi Gelombang Ketiga di Indonesia. Jakarta: Mizan

Undang-Undang Nomor 14 Tahun 2005 Tentang Guru dan Dosen 